\title{
Effect of Planting Date and Nitrogen Fertilization Rates on No-till Pumpkins
}

\author{
E. Ryan Harrelson \\ Soil Science Department, Box 7619, North Carolina State University, \\ Raleigh, NC 27695
}

Greg D. Hoyt ${ }^{1}$

Soil Science Department, North Carolina State University, Mountain Horticultural Crops Research and Extension Center, 455 Research Drive, Fletcher, NC 28732

John L. Havlin

Soil Science Department, Box 7619, North Carolina State University, Raleigh, NC 27695

David W. Monks
Horticultural Science Department, Box 7609, North Carolina State
University, Raleigh, NC 27695

Additional index words. conservation tillage, yield, Cucurbita pepo

\begin{abstract}
Vegetable growers in the Mountain region of North Carolina are faced with increased land prices resulting from urbanization and reduced farm income from lowcommodity prices. Local consumer use of pumpkin (Cucurbita pepo) for jack-o-lanterns and baking provides a fall market for growers to increase production and profitability on-farm. Most soils in these regions are highly erodible and susceptible to drought during the growing season. Little information is available on cultural practices for no-till pumpkin production in this region. Field studies were established to evaluate the yield response of no-till pumpkin to planting date and nitrogen $(N)$ fertilization. Experiments were conducted at the Mountain (MRS), Upper Mountain (UMRS), and the Mountain Horticultural Crops Research Stations (MHCRS) in Summer 2003 and 2004 using no-till cultural practices. Three planting dates were established at 2 -week intervals and 0,40 , 80 , and $120 \mathrm{~kg} \cdot \mathrm{ha}^{-1} \mathrm{~N}$ treatments were applied at each planting date in a randomized complete block design. The 80 and $120 \mathrm{~kg} \cdot \mathrm{ha}^{-1} \mathrm{~N}$ fertilization rates produced greater yields and larger fruit size than the 0 and $40 \mathrm{~kg} \cdot \mathrm{ha}^{-1} \mathrm{~N}$ rates. Pumpkins planted earliest produced the greatest marketable and total yields for all $\mathrm{N}$ rates at all three locations. The latest planting date ( 9 July) and highest $N$ rate yielded more cull fruit compared with marketable pumpkins with the earlier planting date at the Upper Mountain Research Station. This location has a shorter growing season and cooler summer temperatures than the two other locations. Although the third planting date was late for pumpkin planting, higher $\mathrm{N}$ rate treatments at that timing produced marketable yields comparable to earlier planting dates at the two warmer summer locations (MRS and MHCRS). In these experiments, the highest rate applied $\left(120 \mathrm{~kg} \cdot \mathrm{ha}^{-1} \mathrm{~N}\right)$ maximized pumpkin yield. This observation would indicate that higher yields might be possible with even greater $\mathrm{N}$ rates.
\end{abstract}

Most commercial pumpkin production can be found in the northern and central regions of the United States (Pierce, 1987). As urbanization expands into rural areas in

\footnotetext{
Received for publication 27 June 2007. Accepted for publication 14 Dec. 2007.

We express appreciation to the North Carolina Vegetable Growers Association and the USDA/ IFAFS for support of this project; Michael Hannah of Harris Moran Seed Company for donating the pumpkin seed; Anthony Cole of the Department of Soil Science, NCSU, for his technical assistance; the station crews at the Mountain, Upper Mountain, and the Mountain Horticultural Crops Research Stations for field assistance; and Drs. Eugene Kamprath and Deanna Osmond for departmental review of the manuscript.

${ }^{1}$ To whom reprint requests should be addressed; e-mail greg_hoyt@ncsu.edu
}

the Piedmont and Mountain regions of North Carolina, many consumers of farm products now look to local markets for fresh vegetables and value-added farm products. North Carolina farm markets and retail food chains currently are supplied pumpkins from states other than North Carolina. In North Carolina, local consumer use of pumpkin fruit for both jack-o-lanterns and baking provides a fall market for growers to increase production of this commodity.

In the Mountain region of North Carolina, it is especially challenging to produce a profitable crop as a result of variations in topography and weather conditions during the growing season. Much of the land available for pumpkin production in this region is located on soils classified as highly erodible and may be susceptible to drought during some periods of the growing season. Con- ditions of low rainfall, poor weed control, and high pest pressures in the southeastern United States can reduce pumpkin yield and profitability (Stanghellini et al., 2003).

In the Midwest region of the United States, vegetable growers commonly grow pumpkins in no-till production systems. Notill pumpkin production may be a solution to reduce soil erosion on land with relatively high slopes commonly available to growers in the Mountain region of North Carolina. The use of cover crop residues for no-till planting protects the soil surface from erosion by absorbing the impact energy of raindrops, thus reducing soil particle detachment (Hoyt et al., 2004). No-till systems, which leave considerable surface residues from small grains, have yielded well when compared with no residue surfaces in no-till pumpkins (Harrelson et al., 2007). The residue from no-till planting also may improve crop yields by increasing soil moisture compared with conventional tillage (Johnson and Hoyt, 1999). Tillage systems leaving 30\% residue or more after planting generally increase growing season soil moisture as a result of increased infiltration and decreased evaporation (Johnson and Hoyt, 1999). Growers are reluctant to intensively manage pumpkins under irrigation (Stanghellini et al., 2003). Therefore, no-till production can be especially beneficial in reducing potential water stress associated with dryland vegetable crops (Hoyt, 1999).

Many growers are still reluctant to use notill production management as a result of lack of equipment and experience with no-till production. Weed control in no-till vegetable production requires surface applications of preemergence or postemergence herbicides for weed control (Hoyt et al., 1996; Hoyt and Monks, 1996). Weed populations in no-till pumpkins have become easier to control with the recent introduction of a surfaceapplied herbicide that does not require soil incorporation. Selecting appropriate planting dates and fertilization rates are critical for producing high yields of marketable pumpkins.

The objectives of these experiments were to evaluate the yield potential and fruit quality of no-till pumpkins for the Mountain region of North Carolina. The production practices evaluated were nitrogen $(\mathrm{N})$ fertilizer rates and planting dates at three locations. The results of these studies should provide additional information to establish recommendations for optimum no-till pumpkin production in North Carolina.

\section{Materials and Methods}

No-till pumpkin experiments were conducted in 2003 at the Mountain Research Station (MRS) near Waynesville, NC [French loam (a fine-loamy, over sandy, or sandy skeletal, mixed, mesic Fluvaquentic Dystrochrept)] and the Upper Mountain Research Station (UMRS) near Laurel Springs, NC [Toxaway loam (a fine-loamy, mixed, nonacid, mesic Cumulic Humaquept)]. This 
same experiment was planted at the Mountain Horticultural Crops Research Station (MHCRS) near Fletcher in 2003 on a Comus fine sandy loam soil (a course-loamy, mixed, mesic Fluventic Dystrochrepts) but was lost by flooding and was replanted in 2004. This mountain region exhibits cooler average temperatures than those in the eastern Piedmont and Coastal Plain regions. The pumpkin cultivar used at all locations was 'Magic Lantern', which is a large (5.4 to $9.1 \mathrm{~kg}$ ), powdery mildew-resistant variety. Plots were $6.1 \mathrm{~m}$ wide by $7.6 \mathrm{~m}$ long. Each location in 2003 had a rye (Secale cereale) cover crop seeded at $100 \mathrm{~kg} \cdot \mathrm{ha}^{-1}$ in Fall 2002. In 2004 at the MHCRS location, wheat (Triticum aestivum) was used as cover residue, seeded at 100 $\mathrm{kg} \cdot \mathrm{ha}^{-1}$ in Fall 2003. Biomass samples were collected $\left(0.25 \mathrm{~m}^{2}\right)$ at four random locations (one from each replicate) at planting to determine surface residue cover. The residue samples were then sent to the North Carolina Department of Agriculture and Consumer Services Agronomic Division Laboratory for nutrient analyses (Hardy et al., 2003). The small grain cover was allowed to mature until 2 weeks before the first planting date, when all plots were sprayed with paraquat (1,1' -dimethyl-4, 4-bipyridinium dichloride) at $3.5 \mathrm{~L} \cdot \mathrm{ha}^{-1}$ to desiccate the cover crop. A John Deere (Moline, IL) Maxi-merge no-till corn planter (no pumpkin seed was used) was used to open the furrows and simulate the use of a no-till planter. Two to three seeds were hand-seeded at $0.91 \mathrm{~m}$ in-row spacing at each planting date and thinned to one plant per location and 12 plants per plot after seedling emergence. Two rows were established in the plot, $1.83 \mathrm{~m}$ between rows, with $1.66 \mathrm{~m}^{2}$ per plant.

Planting dates at the MRS site were 10 June, 24 June, and 11 July. Recommended planting date for this region is the third week in June. Planting dates for the UMRS site were 11 June, 26 June, and 9 July with a recommended planting date of the second week of June for this cooler mountain location. Planting dates for the 2004 MHCRS location were 17 June, 25 June, and 7 July with the third week in June the recommended planting date. At each planting date, four $\mathrm{N}$ rates $\left(0,40,80\right.$, and $\left.120 \mathrm{~kg} \cdot \mathrm{ha}^{-1} \mathrm{~N}\right)$ as ammonium nitrate were surface broadcastapplied by hand. Soil test results indicated no other nutrients (phosphorus or potassium) were required. Treatments were arranged in a randomized block design with three, four, and four replications of each treatment at the MRS, MHCRS, and UMRS sites, respectively.

Pest management practices included a single application at each planting date of preplant ethalfluralin [n-ethyl-N-(2methyl2-propenyl)-2,6-dinitro-4-(trifluoromethyl benzeneamine] and clomazone [2-(2-chlorophenyl) methyl-4, 4-dimethyl-3-isoxazolidinone] herbicide at $4.6 \mathrm{~L} \cdot \mathrm{ha}^{-1}$ to control weeds. Esfenvalerate [(s)-cyano (3-phenoxyphenyl) methyl (s)-4-chloro-alpha- (1-methylethyl) benzeneacetate] at $0.43 \mathrm{~L} \cdot \mathrm{ha}^{-1}$ was applied once a week after fruit emergence for insect control. Disease control included weekly applications of fungicides azoxystrobin [methyl (E)-2-\{2-[6-(2-cyanophenoxy) pyrimidin-4-yloxy] phenyl $\}-3$-methoxyacrylate] at $0.86 \mathrm{~L} \cdot \mathrm{ha}^{-1}$ and chlorothlonil (tetrachloroisophthalonitrile) at $2.29 \mathrm{~L} \cdot \mathrm{ha}^{-1}$, each applied in alternate weeks starting mid-July at all three locations.

At each location, soil samples were collected to $30-\mathrm{cm}$ depth in $15-\mathrm{cm}$ increments at planting before fertilization from each replicate block within each experiment. Samples were analyzed for available soil $\mathrm{NO}_{3}-\mathrm{N}$ and $\mathrm{NH}_{4}-\mathrm{N}$ by extracting with $1 \mathrm{M} \mathrm{KCl}$ (Keeney and Nelson, 1982) and resulting extractant analyzed for nitrate and ammonium concentrations using an $\mathrm{N}$ analyzer fitted with a cadmium-copper reduction column (Lachat N Analyzer; Lachat Instruments, Milwaukee, WI).

Pumpkin petiole $\mathrm{NO}_{3}-\mathrm{N}$ samples were collected $30 \mathrm{~d}$ after planting at the MHCRS location by randomly sampling four mature petioles from each treatment. The petioles were cut from the vine, $10 \mathrm{~cm}$ cut from the sample (the lower part of the petiole closest to the main vine), and placed in a plastic bag. Samples were placed on ice in the field, moved to a laboratory within $1 \mathrm{~h}$, and processed for nitrate-N. Each petiole was placed in a handheld garlic press, tissue sap dropped onto a Cardy Nitrate Ion Meter, and nitrate recorded (Spectrum Technologies, Plainfield, IL).

Pumpkin fruit was harvested at the MRS location on 3 Oct. $2003(115,101$, and $84 \mathrm{~d}$ after planting), from the UMRS location on 30 Sept. 2003 (111, 96, and 83 d after planting), and from the MHCRS location on 29 Sept. 2004 (104, 96, and 84 d after planting). All fruit within the plots were classified as marketable (U.S. Grade No. 1 or 2) or nonmarketable (cull) and then individually counted and weighed to determine number and weight of marketable and cull fruit. Analysis of variance (PROC ANOVA) was performed with SAS version 6.12 (SAS Institute, Cary, NC). Least significant difference tests were performed to separate treatment differences.

Table 1. Small grain biomass residue and nutrient uptake before no-till pumpkin planting.

\begin{tabular}{|c|c|c|c|c|}
\hline \multirow[b]{2}{*}{ Location } & Biomass & Nitrogen & Phosphorus & Potassium \\
\hline & \multicolumn{4}{|c|}{$\mathrm{kg} \cdot \mathrm{ha}^{-1}$} \\
\hline Mountain Research Station, 2003 & $10,410 \pm 2,254$ & $53 \pm 22$ & $13 \pm 2$ & $61 \pm 7$ \\
\hline Upper Mountain Research Station, 2003 & $4,390 \pm 2,297$ & $59 \pm 49$ & $7 \pm 1$ & $36 \pm 2$ \\
\hline \multicolumn{5}{|l|}{ Mountain Horticultural Crops Research } \\
\hline Station, 2004 & $7,270 \pm 1,028$ & $67 \pm 7$ & $10 \pm 2$ & $53 \pm 14$ \\
\hline
\end{tabular}

Table 2. Soil inorganic nitrogen at no-till pumpkin planting for each location.

\begin{tabular}{llrr}
\hline & $\mathrm{NH}_{4}-\mathrm{N}$ & $\mathrm{NO}_{3}-\mathrm{N}$ & Total inorganic N \\
\cline { 2 - 4 } Location/soil depth & & $\mathrm{kg} \mathrm{ha}^{-1}$ & \\
\cline { 2 - 4 } Upper Mountain Research Station & & & $13.6 \pm 5.4$ \\
$0-15 \mathrm{~cm}$ & $3.9 \pm 2.7$ & $7.1 \pm 2.6$ & $8.5 \pm 2.3$ \\
$15-30 \mathrm{~cm}$ & $1.4 \pm 0.9$ & & \\
Mountain Research Station & & $19.6 \pm 3.3$ & $22.4 \pm 3.0$ \\
$0-15 \mathrm{~cm}$ & $2.8 \pm 0.6$ & $10.9 \pm 0.9$ & $13.7 \pm 3.8$ \\
$15-30 \mathrm{~cm}$ & $2.8 \pm 3.0$ & & $10.4 \pm 5.2$ \\
Mountain Horticultural Crops Res. Station & $8.5 \pm 4.2$ & $14.4 \pm 3.3$ \\
$0-15 \mathrm{~cm}$ & $1.9 \pm 1.0$ & $12.3 \pm 2.5$ & \\
$15-30 \mathrm{~cm}$ & $2.1 \pm 0.8$ & & \\
\hline
\end{tabular}

Surface residue biomass for the MRS site was greater attributable to earlier fall planting and dryer spring soil conditions than the other two locations (Table 1). Nutrient uptake by the small grain residue for all locations removed 52 to $67 \mathrm{~kg} \cdot \mathrm{ha}^{-1} \mathrm{~N}, 7$ to $13 \mathrm{~kg} \cdot \mathrm{ha}^{-1}$ $\mathrm{P}$, and 36 to $61 \mathrm{~kg} \cdot \mathrm{ha}^{-1} \mathrm{~K}$. Removal of $\mathrm{N}$ was similar for each location, although over twice the amount of surface residue was present at the MRS than the UMRS site, reducing the probability that decomposing residue would have any effect on pumpkin response to $\mathrm{N}$ treatments. Soil total inorganic N was from 24 to $36 \mathrm{~kg} \cdot \mathrm{ha}^{-1}$ for the $0-$ to $30-\mathrm{cm}$ depth (Table 2). The MRS site had the greatest amount of total inorganic $\mathrm{N}(0-30 \mathrm{~cm})$ with $36.1 \mathrm{~kg} \cdot \mathrm{ha}^{-1}$ at no-till pumpkin planting.

Plant petiole $\mathrm{NO}_{3}-\mathrm{N}$ concentrations were highly variable among planting date and $\mathrm{N}$ rate treatments (Tables 3, 4, 5, and 6). Petiole $\mathrm{NO}_{3}-\mathrm{N}$ levels generally increased with increasing $\mathrm{N}$ rate. The $\mathrm{NO}_{3}-\mathrm{N}$ concentrations for the last planting date were lower than the earlier planting dates. At the UMRS site, petiole $\mathrm{NO}_{3}-\mathrm{N}$ concentrations may be lower because of the cool weather conditions decreasing plant growth rate and $\mathrm{N}$ fertilization uptake (Table 5).

Mountain Research Station. No-till pumpkin marketable yield $\left(\mathrm{kg} /\right.$ fruit, $\mathrm{t} \cdot \mathrm{ha}^{-1}$, and number of fruit/ha) varied with planting date and $\mathrm{N}$ fertilization rate at this location (Tables 3 and 4). Cull no-till pumpkin yield $\left(\mathrm{t} \cdot \mathrm{ha}^{-1}\right)$ was statistically different $(P<0.01)$ for $\mathrm{N}$ rate with cull yields increasing as $\mathrm{N}$ rate treatments increased. Total no-till pumpkin yield was statistically different for the $\mathrm{t} \cdot \mathrm{ha}^{-1}$ $(P<0.01)$ and number of fruit $\mathrm{ha}^{-1}$ total yield $(P=0.01)$ (Table 3$)$ for the $\mathrm{N}$ rate treatments with no-till pumpkin total yields increasing as $\mathrm{N}$ rate increased. Nitrogen rate treatments affected marketable yields for all parameters (weight per fruit, $\mathrm{t} \cdot \mathrm{ha}^{-1}$, and numbers per hectare) with increased pumpkin marketable yields as nitrogen rate increased (Table 4). No-till pumpkin planting date influenced marketable and total yields with the second 
Table 3. Analysis of variance statistical analyses of the pumpkin experiment.

\begin{tabular}{|c|c|c|c|c|c|c|c|c|c|c|}
\hline \multirow{2}{*}{ Treatment } & \multirow{2}{*}{$\begin{array}{l}\text { Degrees of } \\
\text { freedom }\end{array}$} & \multirow{2}{*}{$\begin{array}{l}\text { Petiole } \\
\text { nitrate }\end{array}$} & \multicolumn{3}{|c|}{ Marketable yield } & \multicolumn{3}{|c|}{ Cull yield } & \multicolumn{2}{|c|}{ Total yield } \\
\hline & & & $\mathrm{kg} /$ fruit & t.ha ${ }^{-1}$ & No. fruit/ha & $\mathrm{kg} /$ fruit & $\mathrm{t} \cdot \mathrm{ha}^{-1}$ & No. fruit/ha & t.ha ${ }^{-1}$ & No. fruit/ha \\
\hline \multicolumn{11}{|c|}{ Upper Mountain Research Station location, 2003} \\
\hline Nitrogen rate & 3 & 0.210 & 0.003 & 0.002 & 0.066 & 0.001 & 0.001 & 0.245 & $<0.001$ & 0.047 \\
\hline Planting date* $\mathrm{N}$ rate & 6 & 0.279 & 0.012 & 0.802 & 0.652 & 0.353 & 0.034 & 0.021 & 0.879 & 0.291 \\
\hline \multicolumn{11}{|c|}{ Mountain Research Station location, 2003} \\
\hline Planting date & 2 & 0.125 & 0.032 & 0.043 & 0.022 & 0.631 & 0.170 & 0.134 & 0.064 & 0.088 \\
\hline \multicolumn{11}{|c|}{ Mountain Horticultural Crops Research Station location, 2004} \\
\hline Planting date & 2 & 0.183 & 0.112 & 0.012 & 0.061 & 0.115 & 0.216 & 0.588 & 0.015 & 0.023 \\
\hline Nitrogen rate & 3 & $<0.001$ & $<0.001$ & $<0.001$ & $<0.001$ & 0.979 & 0.506 & 0.239 & $<0.001$ & $<0.001$ \\
\hline Planting date* $\mathrm{N}$ rate & 6 & 0.860 & 0.643 & 0.702 & 0.019 & 0.492 & 0.506 & 0.184 & 0.604 & 0.260 \\
\hline
\end{tabular}

Table 4. Plant pumpkin yield and petiole nitrate parameters at the Mountain Research Station, 2003 location.

\begin{tabular}{|c|c|c|c|c|c|c|c|c|c|}
\hline \multirow[b]{2}{*}{ Planting date } & \multirow[b]{2}{*}{ Petiole $^{x}$ nitrate } & \multicolumn{3}{|c|}{ Marketable yield } & \multicolumn{3}{|c|}{ Cull yield } & \multicolumn{2}{|c|}{ Total yield } \\
\hline & & $\overline{\mathrm{kg} / \text { fruit }}$ & t.ha ${ }^{-1}$ & No. fruit/ha & $\mathrm{kg} /$ fruit & t.ha ${ }^{-1}$ & No. fruit/ha & $\overline{\mathrm{t} \cdot \mathrm{ha}^{-1}}$ & No. fruit/ha \\
\hline 24 June & 457 & 6.3 & 42.4 & 6,393 & 3.18 & 5.06 & 1,328 & 47.4 & 7,721 \\
\hline \multicolumn{10}{|l|}{ Nitrogen rate } \\
\hline $0^{\mathrm{y}}$ & 805 & 5.6 & 36.2 & 2,867 & 2.71 & 7.58 & 1,993 & 43.7 & 7,859 \\
\hline 40 & 630 & 6.2 & 39.8 & 6,088 & 3.29 & 6.78 & 1,716 & 46.6 & 7,804 \\
\hline$\underline{\operatorname{LSD}(0.05)}$ & 746 & 1.1 & 20.4 & 2,820 & 1.44 & 4.07 & 954 & 21.6 & 2,969 \\
\hline
\end{tabular}

${ }^{2}$ Pooled nitrogen rates for each planting date treatment.

yPooled planting dates for each nitrogen rate treatment.

${ }^{x}$ Petiole nitrate- $\mathrm{N}$ in ppm measured $30 \mathrm{~d}$ after each planting date.

LSD $=$ least significant difference; $\mathrm{NS}=$ nonsignificant.

Table 5. Plant pumpkin yield and petiole nitrate parameters at the Upper Mountain Research Station, 2003 location.

\begin{tabular}{|c|c|c|c|c|c|c|c|c|c|}
\hline \multirow[b]{2}{*}{ Planting date } & \multirow[b]{2}{*}{ Petiole $^{\mathrm{x}}$ nitrate } & \multicolumn{3}{|c|}{ Marketable yield } & \multicolumn{3}{|c|}{ Cull yield } & \multicolumn{2}{|c|}{ Total yield } \\
\hline & & $\mathrm{kg} /$ fruit & t.ha ${ }^{-1}$ & No. fruit/ha & $\overline{\mathrm{kg} / \text { fruit }}$ & t.ha ${ }^{-1}$ & No. fruit/ha & $\overline{\mathrm{t} \cdot h \mathrm{a}^{-1}}$ & No. fruit/ha \\
\hline 26 June & 1,178 & 2.9 & 9.9 & 2,564 & 1.83 & 3.73 & 1,420 & 13.7 & 3,983 \\
\hline \multicolumn{10}{|l|}{ Nitrogen rate } \\
\hline $0^{\mathrm{y}}$ & 404 & 1.3 & 4.8 & 1,828 & 1.03 & 2.18 & 1,261 & 7.0 & 3,088 \\
\hline 40 & 530 & 2.6 & 7.5 & 1,974 & 1.59 & 3.10 & 1,581 & 10.6 & 3,555 \\
\hline LSD $(0.05)$ & 930 & 1.53 & 6.7 & 1,381 & 0.95 & 2.74 & NS & 8.0 & 1,757 \\
\hline
\end{tabular}

${ }^{2}$ Pooled nitrogen rates for each planting date treatment.

${ }^{\mathrm{y}}$ Pooled planting dates for each nitrogen rate treatment.

xetiole nitrate- $\mathrm{N}$ in ppm measured $30 \mathrm{~d}$ after each planting date.

LSD $=$ least significant difference; $\mathrm{NS}=$ nonsignificant.

Table 6. Plant pumpkin yield and petiole nitrate parameters at the Mountain Horticultural Crops Research Station, 2004 location.

\begin{tabular}{|c|c|c|c|c|c|c|c|c|c|}
\hline \multirow[b]{2}{*}{ Planting date } & \multirow[b]{2}{*}{ Petiole $^{\mathrm{x}}$ nitrate } & \multicolumn{3}{|c|}{ Marketable yield } & \multicolumn{3}{|c|}{ Cull yield } & \multicolumn{2}{|c|}{ Total yield } \\
\hline & & $\overline{\mathrm{kg} / \text { fruit }}$ & t.ha ${ }^{-1}$ & No. fruit/ha & $\mathrm{kg} /$ fruit & $t \cdot h^{-1}$ & No. fruit/ha & $\mathrm{t} \cdot \mathrm{ha}^{-1}$ & No. fruit/ha \\
\hline 25 June & 1,278 & 5.7 & 39.5 & 6,880 & 0.51 & 0.80 & 467 & 40.3 & 7,347 \\
\hline LSD $(0.05)$ & NS & NS & 9.3 & 1,752 & NS & NS & NS & 10.3 & 1,533 \\
\hline \multicolumn{10}{|l|}{ Nitrogen rate } \\
\hline $0^{\mathrm{y}}$ & 467 & 3.7 & 18.2 & 4,732 & 1.12 & 0.79 & 249 & 19.0 & 4,981 \\
\hline 40 & 936 & 5.1 & 30.2 & 5,894 & 1.10 & 1.42 & 540 & 31.6 & 6,434 \\
\hline LSD $(0.05)$ & 492 & 0.9 & 8.4 & 922 & NS & NS & 695 & 9.0 & 1,314 \\
\hline
\end{tabular}

${ }^{\mathrm{z}}$ Pooled nitrogen rates for each planting date treatment.

yPooled planting dates for each nitrogen rate treatment.

xPetiole nitrate- $\mathrm{N}$ in ppm measured $30 \mathrm{~d}$ after each planting date.

LSD = least significant difference; $\mathrm{NS}=$ nonsignificant. 
planting date decreasing pumpkin yield parameters. At this location, planting pumpkins at an earlier planting date than that recommended in North Carolina resulted in greater weights and numbers of no-till pumpkins than the two later planting dates. No planting date by nitrogen rate treatment interactions were measured for this location.

Upper Mountain Research Station. Similar to the MRS location, all marketable yield measurements $\left(\mathrm{kg} /\right.$ fruit, $\mathrm{t} \cdot \mathrm{ha}^{-1}$, and number of fruit/ha) were statistically significant at the $P$ $=0.05$ level for the planting date and $\mathrm{N}$ rate treatments (Tables 3 and 5). At the UMRS, yields decreased as planting date went from 11 June (first planting date) to the third planting date (9 July) (Table 5). There was a planting date by $\mathrm{N}$ rate interaction for the $\mathrm{kg} /$ fruit measurements with the 9 July planting date treatment having lower fruit weights at low $\mathrm{N}$ rates compared with the earlier planting dates and the $120 \mathrm{~kg} \cdot \mathrm{ha}^{-1} \mathrm{~N}$ rate $(9$ July planting date) with very high individual fruit weights (Fig. 1). Cull no-till pumpkin yield $\left(\mathrm{kg} /\right.$ fruit and $\left.\mathrm{t} \cdot \mathrm{ha}^{-1}\right)$ was statistically different $(P<0.01$ and $<0.01$, respectively) for $\mathrm{N}$ rate and total no-till pumpkin yield was statistically different for both the $\mathrm{t} \cdot \mathrm{ha}^{-1}$ $(P<0.01)$ and number of fruit/ha total yield $(P=0.05)$ (Table 3).

Mountain Horticultural Crops Research Station. No-till pumpkin marketable yield $\left(\mathrm{t} \cdot \mathrm{ha}^{-1}\right)$ was statistically different for planting date $(P=0.01)$, in which yield with the third planting was significantly lower than the earlier dates (Tables 3 and 6). All marketable no-till pumpkin measurements $(\mathrm{kg} /$ fruit, $\mathrm{t} \cdot \mathrm{ha}^{-1}$, and number of fruit/ha) were significantly influenced by $\mathrm{N}$ rate $(P=0.01)$. There was a planting date by $\mathrm{N}$ rate interaction for the no-till pumpkin measurement of number of marketable fruit/ha with yields very low for the 7 July planting date at the $0 \mathrm{~kg} \cdot \mathrm{ha}^{-1} \mathrm{~N}$ rate compared with the first two planting dates (17 and 25 June 17) (Fig. 2). Cull notill pumpkin yields produced no statistical differences for any of the measurements. Total no-till pumpkin yield $\left(\mathrm{t} \cdot \mathrm{ha}^{-1}\right.$ and number of fruit/ha) for the MHCRS location was significantly influenced by both planting date and $\mathrm{N}$ rate measurements (Tables 3 and 6).

\section{Conclusions}

This research showed that no-till pumpkins can be grown in North Carolina and that fruit weights are similar to those projected by the seed company source (Harris Moran Seed Company Pumpkin Guide) and similar experiments comparing no-till with and without residue (Harrelson et al., 2007). By using notillage practices, producers should be able to improve pumpkin yields in low rainfall locations from the additional soil moisture retained by the surface residues (Hoyt and Konsler, 1988; Wagger, 1993). These results showed that planting no-till pumpkins at planting dates recommended for conventional tillage could result in reductions in no-till pumpkin yields on soils and in locations where soil temperature is lower and

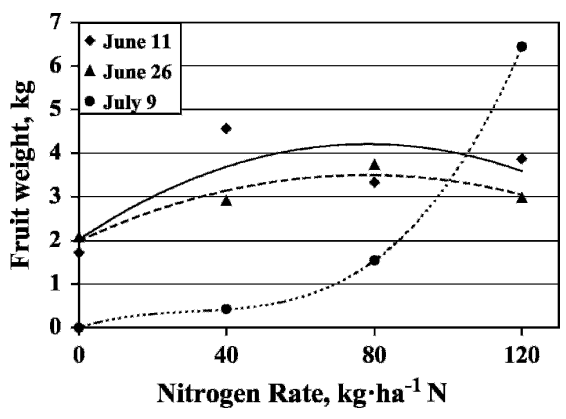

Fig. 1. Effect of nitrogen fertilizer application rate and planting date on marketable pumpkin fruit weight, Upper Mountain Research Station, 2003. Dates indicate planting dates.

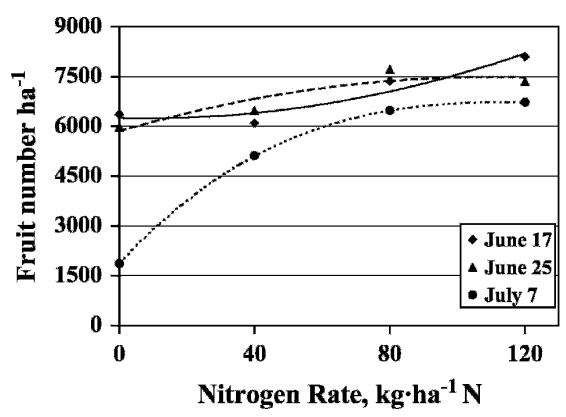

Fig. 2. Effect of nitrogen fertilizer application rate and planting date on marketable pumpkin fruit number, Mountain Horticultural Crops Research Station, 2004. Dates indicate planting dates.

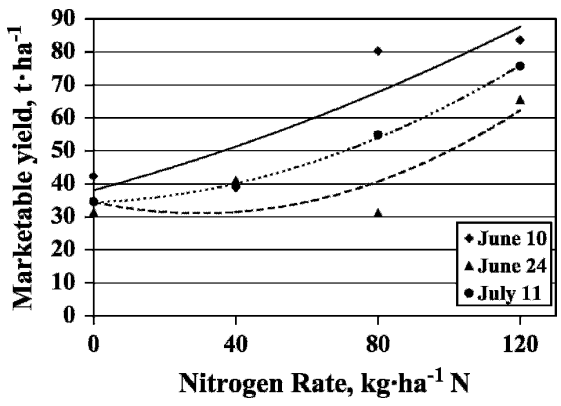

Fig. 3. Effect of nitrogen fertilizer application rate and planting date on marketable pumpkin fruit yield, Mountain Research Station, 2003.

have a shorter growing season than the region (Figs. 3, 4, and 5). These experiments confirm the need for more $\mathrm{N}$ in no-till pumpkins than the current recommended rate of 100 $\mathrm{kg} \cdot \mathrm{ha}^{-1} \mathrm{~N}$ for conventional tillage pumpkins (Schultheis, 1998). Other recommendations suggest that an additional 20 to $30 \mathrm{~kg} \cdot \mathrm{ha}^{-1}$ will improve yields of conservation-tilled vegetables (Sanders, 2006). In this experiment, the highest rate applied $\left(120 \mathrm{~kg} \cdot \mathrm{ha}^{-1} \mathrm{~N}\right)$ maximized pumpkin yield at each location and for each planting date (Figs. 3, 4, and 5). These higher nitrogen rates also produced greater petiole nitrate concentrations (1780

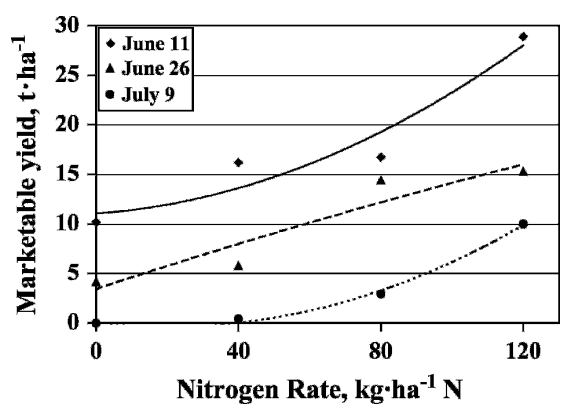

Fig. 4. Effect of nitrogen fertilizer application rate and planting date on marketable pumpkin fruit yield, Upper Mountain Research Station, 2003.

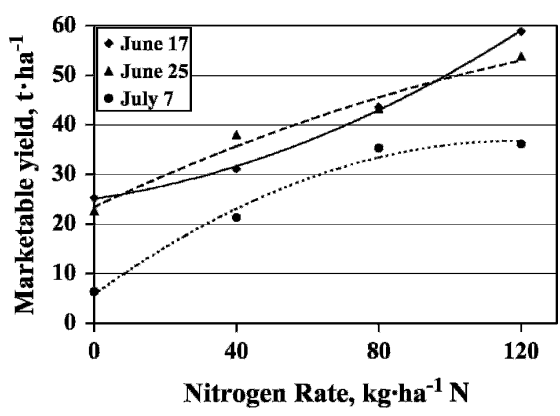

Fig. 5. Effect of nitrogen fertilizer application rate and planting date on marketable pumpkin fruit yield, Mountain Horticultural Crops Research Station, 2004.

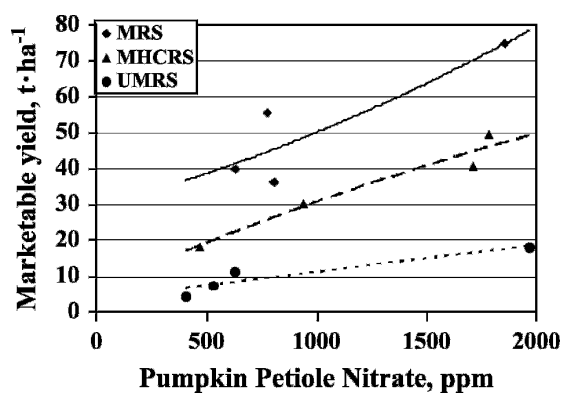

Fig. 6. Effect of pumpkin petiole nitrate concentration on marketable yield. MRS = Mountain Research Station; MHCRS = Mountain Horticultural Crops Research Station; UMRS = Upper Mountain Research Station. Data represents $\mathrm{N}$ rate petiole nitrate and marketable yield from pooled planting date for each location.

to $1956 \mathrm{ppm}$ ) that correlated to the higher marketable yields (Fig. 6). These observations would indicate that higher yields might be possible with even greater $\mathrm{N}$ rates. More experimentation is needed with no-till pumpkins to establish the optimum $\mathrm{N}$ rate.

\section{Literature Cited}

Hardy, D.H., M.R. Tucker, and C.E. Stokes. 2003. Crop fertilization based on North Carolina Soil tests. 15 Feb. 2007. <http://www.ncagr.com/ agronomi/pdffiles/obook.pdf>. 
Harrelson, E.R., G.D. Hoyt, J.L. Havlin, and D.W. Monks. 2007. Effect of winter cover crop residue on no-till pumpkin yield. HortScience 42:1568-1574.

Hoyt, G.D. 1999. Tillage and cover residue affects on vegetable yields. HortTechnology 9:351358.

Hoyt, G.D., A.R. Bonanno, and G.C. Parker. 1996. Influence of tillage and herbicides on yield and quality of cabbage. Weed Technology. 10:50-54.

Hoyt, G.D. and T.R. Konsler. 1988. Soil water and temperature regimes under tillage and cover crop management for vegetable culture, $p$. 697-702. Proc. of the 11th International Conference, ISTRO, Edinburgh, Scotland.
Hoyt, G.D. and D.W. Monks. 1996. Weed management in strip-tilled Irish and sweet potato production. HortTechnology 6:238-241.

Hoyt, G.D., M.G. Wagger, C.R. Crozier, and N.N Ranells. 2004. Winter annual cover crops. AGW 439-58. 10 Mar. 2007.<http://www.soil. ncsu.edu/publications/Soilfacts/AGW-439-58/ AGW_439_58.pdf>.

Johnson, A.M. and G.D. Hoyt. 1999. Changes to the soil environment under conservation tillage. HortTechnology 9:380-393.

Keeney, D.R. and D.W. Nelson. 1982. Nitrogen forms, p. 643-698. In: Page, A.L. (ed.). Methods of soil analysis, part 2. 2nd Edition. ASA Spec. Pub. 9. ASA and SSSA, Madison, WI.
Pierce, L.C. 1987. Vegetables: Characteristics, production and marketing. Wiley, New York, NY.

Sanders, D.C. (ed.). 2006. Southeastern U.S. 2006 Vegetable Crop Handbook. Vance Publishing Corporation, Lincolnshire, IL.

Schultheis, J.R. 1998. Growing pumpkins and winter squash. N.C. Coop. Ext. Serv. Lfit. HIL-24.

Stanghellini, M.S., J.R. Schultheis, and G.J. Holmes. 2003. Adaptation and market potential of jack o' lantern and miniature pumpkin cultivars in eastern North Carolina. HortTechnology 13:532-539

Wagger, M.G. 1993. Role of cover crops in soil water and nitrogen dynamics. Soil Sci. Soc. N.C. Proc. 36:59-60. 